\title{
Pathomorphological Assessment of Sub-Acute Dermal Toxicity of Morinda citrifolia Linn. Fruit Extract Coated Gold Nano Particles in Wistar Rats
}

\author{
A. R. Pawar $^{1}$, S. R. Rajurkar ${ }^{1}$, N. D. Jadhav ${ }^{\text {* }}$, G. R. Gangane ${ }^{2}$ and S. Bhalchim ${ }^{2}$ \\ ${ }^{I}$ Department of Veterinary Pharmacology and Toxicology, India \\ ${ }^{2}$ Department of Veterinary Pathology, India \\ College of Veterinary and Animal Sciences, Parbhani 431402, India \\ Maharashtra Animal and Fishery Sciences, University, Nagpur, India \\ *Corresponding author
}

\section{Keywords}

Sub-acute dermal toxicity, Morinda citrifolia, Pathomorphology in dermal toxicity, Gold Nano particles.

\section{Article Info}

Accepted:

18 August 2019 Available Online: 10 September 2019

\section{A B S T R A C T}

Gold nanoparticles (GNPs) an emerging part of nanomedicine holds great promise for revolutionizing medical treatments and therapies in areas such as imaging, drug delivery, faster diagnosis, and tissue regeneration, as well as the development of new medical products. But their safety assessment is a major concern. As body system reacts in a different way than isolated cell line than artificial environment, so in the present experiment pathomorphological assessment ofsub-acute dermal toxicity of green synthesized GNPs and coating with Morinda citrifolia fruit extract (McFE) was undertaken. Gold nanoparticles were synthesized by biological reduction of chloroauric acid with Azadirachta indica (neem) 5\% leaf extract. The nanoparticles characterized and were confirmed by colour changes from pale yellow to ruby red. These nanoparticles were coated with McFE.For toxicity evaluation.50 Wistar rats of either sex were assigned to five groups. One group was considered healthy, three groups received dermal application of combination of $1 \mathrm{mg} / \mathrm{kg}$ GNPs with $150 \mathrm{mg} / \mathrm{kg}$ McFE (Low dose), $2 \mathrm{mg} / \mathrm{kg}$ GNPs with $300 \mathrm{mg} / \mathrm{kg} \mathrm{McFE} \mathrm{(Medium} \mathrm{dose)} \mathrm{and} 4 \mathrm{mg} / \mathrm{kg}$ GNPs with $600 \mathrm{mg} / \mathrm{kg}$ McFE (High dose) dermal application for 28 days. The last group was considered as satellite group which received $8 \mathrm{mg} / \mathrm{kg}$ GNPs with 1200 $\mathrm{mg} / \mathrm{kg}$ McFE and observed for extra 14 day beyond trial period for checking post withdrawal effect. Grossly mild hemorrhages, congestion and architectural alteration were observed in liver and kidney treated with highest dose. However the histopathological examination of skin revealed no alteration in skin architecture but minimal alterations were observed in liver and kidney where major changes like dilatation of central vein and sinusoidal space, multifocal necrobiotic changes and focal fatty change in liver and cystic degeneration and hyaline cast in lumen of kidney noticed indicating proper absorption and excretion of GNPs from body. 


\section{Introduction}

Nanoparticles has multifunctional properties and very interesting applications in various fields such as medicine, nutrition, and energy ${ }^{1}$. From as early as $2500 \mathrm{BC}$, the therapeutic benefits of gold preparations have been reported in Indian, Arabic, and Chinese literature $^{2}$. Swarna (gold) bhasma has been utilized as a therapeutic indian ayurvedic medicine for several clinical disorders including bronchial asthma, rheumatoid arthritis, diabetes mellitus ${ }^{3}$. Nano-medicine is widely seen as having huge potential to bring profits to many areas of research and applications and it can be uses to maintain, monitor, treat, and prevent diseases. Gold nanoparticles have a wide scope of applications in molecular biology and biomedicine, which includes cell/biomedical imaging, biosensing, peptide delivery and drug delivery ${ }^{4}$.

Gold nanoparticles (AuNPs), an emerging nano-medicine is renowned for its promising therapeutic possibilities, due to its significant properties such as biocompatibility, high surface reactivity, resistance to oxidation and surface plasmon resonance ${ }^{5}$. Gold nanoparticles are compatible for a wide range of biological applications, because of their unique physical and chemical properties. Recently, the applications of gold nanoparticles have expanded into various biomedical fields (biosensors, immunoassays, genomics, photo thermolysis of cancer cells, microorganisms detection and control, targeted drug delivery, optical imaging, monitoring of biological cells and tissues by exploiting resonance scattering, or in vivo photo acoustic techniques ${ }^{6}$. The role of gold nanoparticles invading the treatment for various inflammatory diseases, other relative disorders and in modern medicine, gold nanoparticles find significant applications in drug delivery system as they are capable of encapsulating active drugs and targeting ${ }^{7}$.Gold NPs have very unique physicochemical properties and capability of easy functionalization, binding to amine and thiol groups. All these characteristics possessed by gold NPs pave the way for surface modification and are being investigated as drug carriers in cancer and thermal therapy and as contrast agent.

Morinda citrifolia belongs to family Rubiacea ${ }^{8}$.Indian mulberry (Noni) is a small to medium sized evergreen tree that is widely distributed in the tropics. The leaves are 8-10 inches long, oval shaped; dark green and shiny with deep veins ${ }^{9}$.

Noni is largely used in traditional medicine and has wide range of uses; including arthritis, atherosclerosis, boils, burns, cancer, chronic fatigue syndrome, circulatory weakness, cold sores, congestion, constipation, diabetes, gastric ulcers, gingivitis, heart disease, hypertension and infections ${ }^{10}$. Several reports have described various potential health benefits of $M$. citrifolia fruit including immune modulation and antioxidant activities in vitro and in vivo ${ }^{11}$ and in vivo antihyperlipidemic effect $^{12}$. Since the efficacy ofMorinda citrifolia Linn. as an antidiabetic and antihypertensive, antioxidant, antihyperlipidemic and AuNPs as potent drug delivery system are proved, the investigations on the efficacy of gold nano particle alone and Morinda citrifolia Linn. coated gold nano particles is studied in the department of Veterinary Pharmacology \& Toxicology, College of Veterinary \& Animal Sciences, Parbhani, it is necessary to study the adverse or toxic effects if any of the same.

Morinda citrifolia Linn fruit extract contains the anti-inflammatory activity when given internally well as when applied locally, thus the extract is expected to be applied over skin and looking to this the safety evaluation of the 
plant and extract coated gold nanoparticles is essential.Morinda citrifolia Linn. fruit extract possess antitumor activity and hence its local application is also expected. Morinda citrifolia Linn fruit extract coated gold nanoparticles are also expected to be given through skin as an external application. It is necessary to evaluate the same for its dermal toxicity.

Department of Veterinary Pharmacology \& Toxicology, COVAS, Parbhani since last 5 years is working on synthesis of metal nanoparticles, its coating with herbal extracts and efficacy studies of the same. To draw a fruitful recommendation on the use of Morinda citrifolia Linn coated gold nano particles it is necessary to investigate its toxic effects. Hence, present study is proposed to investigate possible health hazards likely to arise from repeated dermal exposure over 28 days ${ }^{13}$.

\section{Materials and Methods}

The present investigation was carried out on 50 wistar rats in small animal laboratory house, Department of Veterinary Pharmacology and Toxicology, College of Veterinary and Animal Sciences, Parbhani, MAFSU, Maharashtra.

\section{Experimental animals}

Experimental animals (Wistar rats) were purchased from Sanzyme,Ltd. Hyderabad. The present study was conducted on 50 Wistar rats of either sex. The animals were selected to be within a weight range 200-250 g for each sex and age ranges from 8-10 weeks. Wistar rats were housed in small animal lab house room no.3 in standard laboratory conditions, provided with ad-libitum food and water. The Institutional Animals Ethical Committee (IAEC) approved the experimental protocol vide Resolution no. IAEC/09/17 dated 18/02/2017. All necessary managemental procedures were adopted to keep the animals free from stress.

\section{Husbandry}

Housing : Cage system

Temperature $\quad: 22 \pm 3^{\circ} \mathrm{C}$

Relative Humidity : $30-70 \%$

Photoperiod : $12 \mathrm{hr}$ dark \& $12 \mathrm{hr}$

light

Light intensity $\quad: 130-140$ Lux

Food $\quad:$ Pelleted diet

Water : Clean purified water

\section{Acclimatization, grouping and} identification of experimental animals

Wistar rats were acclimatized to experimental room condition for five days. After acclimatization to the experimental conditions all the 50 Wistar rats were randomly divided into five groups, each containing 10 rats of either sex. All the animals were maintained for the experimental period of 28 days except the satellite group, which was maintained for 14 more days but without any treatment, only under observation for reversibility, persistence, or delayed occurrence of toxic effects or to study the post withdrawal effect with highest dose given. Wistar rats were kept individually in separate cages, each cage were identified with a label, cage no, group details, treatment type and marking were specific to identify the animals.

\section{Drugs and chemicals}

\section{Gold chloride}

Gold chloride was used to produce gold nanoparticles (GNPs) by biological reduction method by using Azadirachta indica (neem) leaf extract.

Compound name : Chloroauric acid Extra Pure ACS Chemical name : Tetrachloroauric (III) acid trihydrate Moecular.weight. : 339.79 (anhydrous basis) 


$\begin{array}{ll}\text { Product code } & : 0273400001 \\ \text { Molecular formula } & : \mathrm{HAuCl}_{4} .3 \mathrm{H}_{2} \mathrm{O} \\ \text { Batch No. } & : \text { L223221703 } \\ \text { Company } & : \text { LOBA CHEMIE PVT. } \\ \text { LTD, } & \text { MUMBAI } \\ & : \text { Yellow colored powder } \\ \text { Physical appearance } & : 0-4^{0} \mathrm{C} \\ \text { Storage condition } & : \text { Deionised water } \\ \text { Vehicle } & \\ & \\ \text { Morinda citrifolia } & \text { (Noni) } \\ \text { Botanical name } & : \text { Morinda citrifolia } \\ \text { Family } & : \text { Rubiaceae (coffee } \\ \text { family) } & \\ \text { Common name } & : \text { Indian mulberry, } \\ & \text { beach mulberry, } \\ & \text { great morinda } \\ \text { English } & : \text { Noni } \\ \text { Hindi } & : \text { Bartundi } \\ \text { Sanskrit } & : \text { Ayushka } \\ \text { Marathi } & : \text { Nagakunda } \\ \text { Gujarati } & : \text { Surangi }\end{array}$

\section{Morinda citrifolia (Noni) fruits extract}

Aqueous extract of Morinda citrifolia L. fruit was prepared by cold extraction method. Noni fruits were procured from the College of Food Science and Technology, VNMKV, Parbhani(Fig no-3). They were cut into pieces and allowed to dry completely under shade. Dried fruit pieces were ground to powder with the help of an electric grinder.

Then, 20\% aqueous solution was made by dissolving 200 grams of powder in double distilled water and the final quantity was made to 1 liter. It was mixed thoroughly and allowed to soak for 48 hours at $4^{\circ} \mathrm{C}$ in refrigerator with intermittent shaking using an electrically operated flask shaker.

Thus, resulting solutions was first filtered by using muslin cloth and then by filter paper in to glass plates. They were allowed to dry under shade and hence aqueous extract of Morinda citrifolia was obtained.
The weight of empty glass plates were noted and final weight after drying was obtained. Resulting extracts were scraped off the glass plate and stored in a container at $4^{0} \mathrm{C}$ for dosing of rats during experiment.

\section{Preparation of site for drug application}

Fur of all the experimental animals was clipped from dorsal area of the trunk under the inhalation anesthesia (di-ethyl ether) using an electric clipper, followed by manual shaving using razor blade.

Based on OECD guideline 410, not less than $10 \%$ of the body surface area was cleared for the application of the test substance. The dorsal area was applied with the Morinda citrifolia Linn. fruit extract coated GNPs. Animals were applied with the test substance for 6 hours per day on a 7-day per week basis, for a period of 28 days (Figure 2 ).

\section{Experimental design}

Table 1 shows experimental design, distribution of different groups and treatment given. Group -I is taken as healthy control.

Group -II, III and IV are treated with different doses of Morinda citrifolia coated GNPs. Group $-\mathrm{V}$ is taken as satellite group with highest dose of Morinda citrifolia coated GNPs. Each group contains 10 animals of either sex.

\section{Organ weight}

The absolute organ weights of liver, kidney and heart were noted in control and post treatment sacrificed Wistar rats.

\section{Pathological observations}

All the rats in each group were sacrificed on the termination of the experiment and the 
organs were subjected to the gross and microscopic examinations.

\section{Gross pathology}

The organs in experimental sacrificed Wistar rats were observed for the presence of any abnormal gross pathological change.

\section{Histopathological changes}

Liver, kidney and skin tissue were collected in 10 percent formalin and were dehydrated in ascending grade of alcohol, cleared in xylene and embedded in paraffin wax. Four to five micron thick sections were stained with routine Haematoxylin and Eosin-staining method and examined ${ }^{14}$.

\section{Statistical analysis}

The data obtained from various parameters from all the groups was analyzed by as per method suggested by using factorial randomized block design (FRBD) and completely randomized block design (CRD) as per requirement and interpreted ${ }^{15}$.

\section{Results and Discussion}

\section{Morinda citrifolia fruit extract preparation}

For the preparation of Morinda citrifolia fruit extract $8.500 \mathrm{~kg}$ fresh fruit was collected. After shade drying and maceration, $3.200 \mathrm{~kg}$ fruit powder was obtained. Hence by this procedure dry matter \% was found to be $37.64 \%$. all the powder was processed for extract preparation and $143 \mathrm{~g}$ aqueous extract was obtained. Percent extractability by this method was found to be $4.46 \%$.

Synthesis, coating and characterization GNPs

Synthesis of gold nanoparticles was confirmed by color change, which was very well visible to naked eye. When $9 \mathrm{ml}$ of $1 \mathrm{mM}$ chloroauric acid solution (faint yellow) was reacted with $1 \mathrm{ml}$ of $5 \%$ extract of Azadirachta indica (neem) leaves (also faint yellow colour), immediately colour change was observed. After 30 minutes of incubation, solution turned to ruby red to violet colour. When the tubes were left for 2 hours of incubation the colour intensified and tuned to reddish-black colour. To confirm this colour change was due to the formation of gold nanoparticles, one chloroauric acid control (1mM, 10ml) and another extract control $(9 \mathrm{ml}$ distilled water + $1 \mathrm{ml} 5 \%$ Azadirachta indica leaf extract) was maintained. The colour change was compared to them as shown in (Figure 1).

\section{Gross examination}

The gross pathological examination was carried out at the end of the experimental period in sacrificed rats of all experimental groups. The gross examination revealed mild degree of affections like petechial hemorrhages, slight congestion seen in treatment groups. Similarly congestion of mild to moderate degree along with multifocal hemorrhages was seen in kidney of high doses group. Skin did not reveal any appreciable gross pathological changes in any of the treatment groups as shown in (Figure 4).

\section{Relative Organ Weights}

Mean organ weights in grams of liver, kidney and heart in different groups were recorded after gross pathological examination. The details are given in Table-2.

The absolute organ weights of Liver, Kidneys and Heart of all the experimental rats were taken at the end of study period. The absolute organ weights of Liver, Kidneys and Heart were ranged between $6.65 \pm 0.36$ to $8.45 \pm 0.71$, $1.78 \pm 0.12$ to $2.24 \pm 0.11$ and $0.91 \pm 0.06$ to $1.21 \pm 0.08$ respectively. These values did not 
showed significant variations except the mean values of heart weight in the rats of group found to be increased significantly as compare to respective healthy control group indicating minimal toxicity induction.

Superscripts a,b,c,d,e shows significant difference within the column (between different groups on specific day) $(p=0.05)$. Superscripts p,q,r shows significant difference within the row (between different days in specific groups) $(p=0.05)$

\section{Histopathological alterations}

The histopathological alterations found in liver, kidney and skin of rats of healthy control and Morrinda citrifolia fruit extract coated GNPs treated groups are described as follows.

\section{Liver}

Liver from the experimental rats of Morinda citrifolia fruit extract coated GNPs dose III (group- IV).

On its histoarchitectural studies revealed congestion, focal mononuclear cell infiltration and degenerative changes $(\mathrm{H} \& \mathrm{E}$ Stain, $\mathrm{X} 400$ )as shown in (Figure 5). Multifocal fatty change and mononuclear cell infiltration in parenchyma of liver (H\&E Stain, X400)as shown in (Figure 6).Liver with moderate cytoplasmic rarefication and occasional fatty change (H \& E Stain, X400) as shown in (Figure 7).

Also, the liver of experimental rats of group Morinda citrifolia fruit extractcoated GNPs dose I \& II (group II \& III) when subjected for histopathology noted minimal congestion \& focal mononuclear cell infiltration. The histopathological alterations observedare in close approximation with the present findings ${ }^{16-19}$.

\section{Kidney}

The histopathological examination of kidneys from experimental rats of Morinda citrifolia fruit extract coated GNPs dose III (group IV) revealedcongestion and mononuclear cell infiltration in Kidney (H \&E Stain, X400) asshown in (Figure 8), multifocal cystic, vacuolar degenerative changes and mononuclear cell infiltration in Kidney $(\mathrm{H} \&$ E Stain, X100) as shown in (Figure 9).Section of a Kidney with vacuolar degenerative changes, necrobiotic changes and mononuclear cell infiltration (H \& E Stain, $\mathrm{X} 400$ )as shown in (Figure 10), focal hyaline cast in lumen of proximal convoluted tubules and necrobiotic changes in affected tubules $(\mathrm{H}$ \& E Stain, X400) as shown in(Figure 11).However the sections of kidneys of Morinda citrifolia fruit extract coated GNPs dose I \& II (group II \& III) revealed mild congestion and mononuclear cell infiltration with occasional degenerative changes. These histopathological changes are also reported by several workers ${ }^{17-19}$.

\section{Skin}

The histopathological studies of all experimental rats did not show any appreciable change in any of the skin section examined. A section of skin with normal histoarchitecture (H \& E Stain, X100) as shown in (Figure 12) and (H \& E Stain, X400) as shown in (Figure 13). The similar changes reported by zahi ${ }^{20}$. 
Fig.1 Confirmation of Gold nanoparticles formed by observing colour change through naked eye

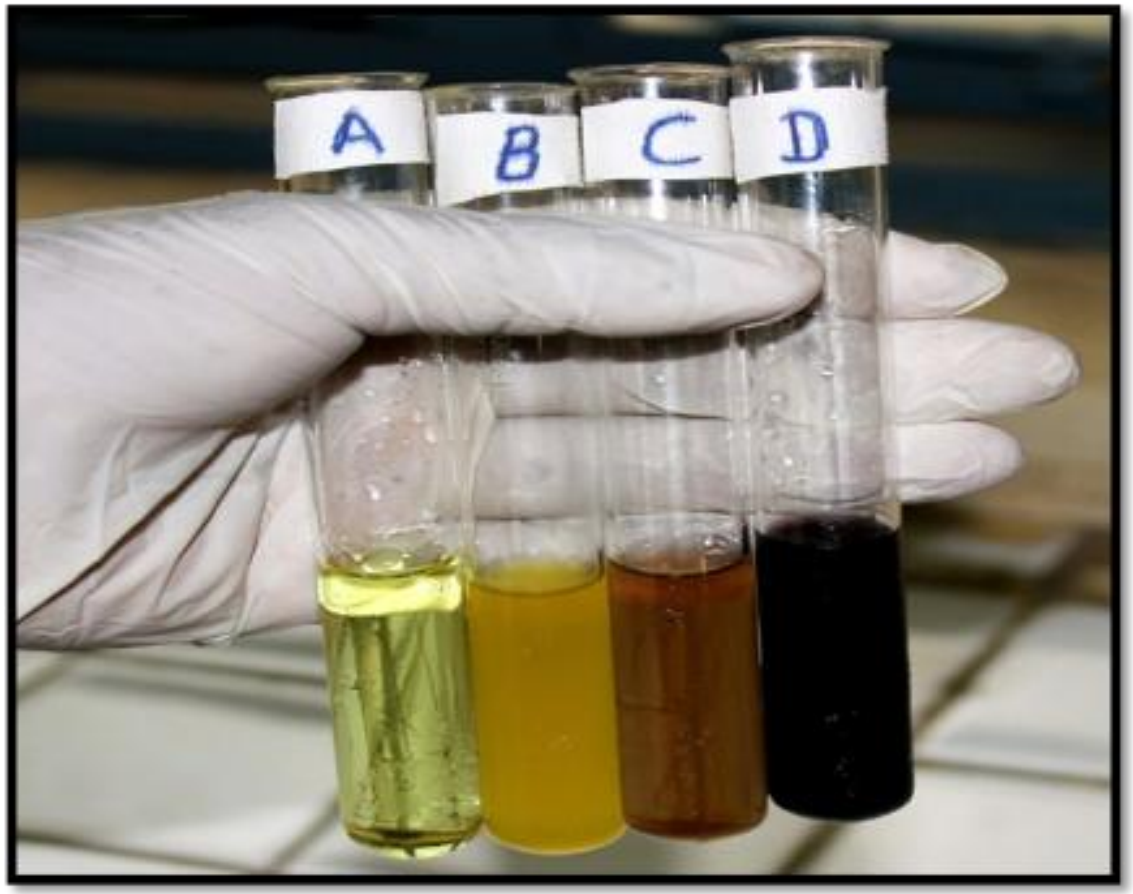

A . Natural colour of $1 \mathrm{mM}$ solution of chloroauric acid

B. Natural colour of 5\% aqueous leaf extracts of Azadirachta indica(Neem) Plant

C. Ruby red color formed after addition of $1 \mathrm{mM}$ solution of chloroauricacid and $5 \%$ aqueous leaf extracts of Azadirachta indica (Neem) Plantand 0.5 hour of incubation

D. Ruby red color darkens to reddish black after addition of $1 \mathrm{mM}$ solutionof chloroauric acid and $5 \%$ aqueous leaf extracts of Azadirachta indica (Neem) Plant and 2 hour of incubation

Fig.2 Preparation of site for dermal application of Fig.3 Morinda citrifolia(noni)fruit drug
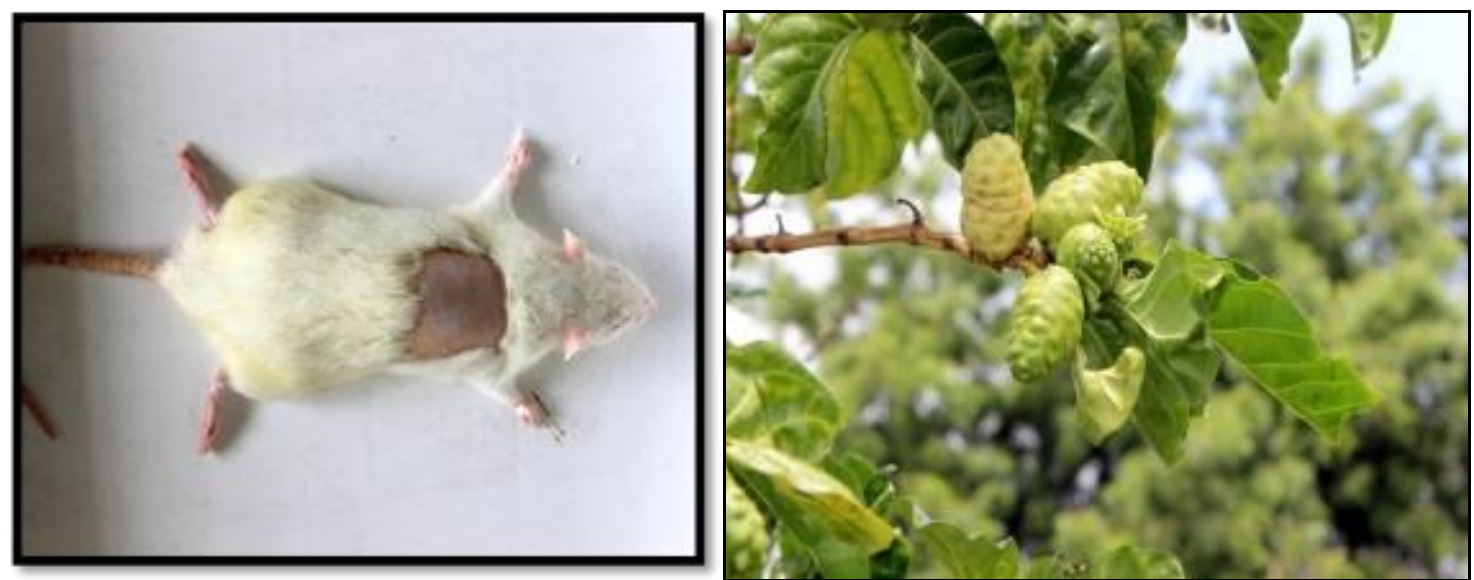
Fig.4 Gross examination of organs at the time of sacrifice 1.Liver 2.Kidney 3.Heart

A) Healthy Control, B) Highest dose of coated GNPs

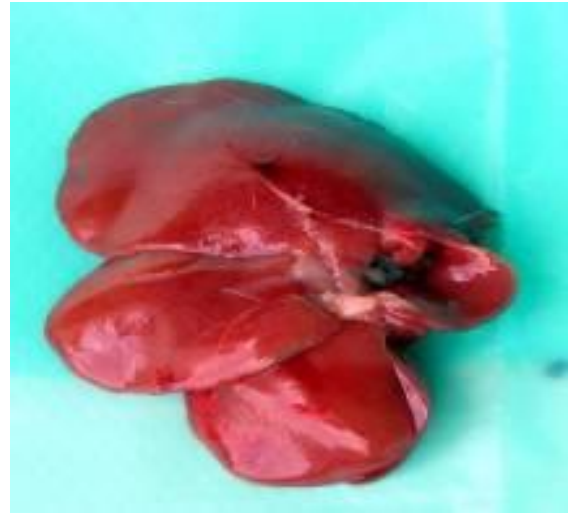

1.(A)

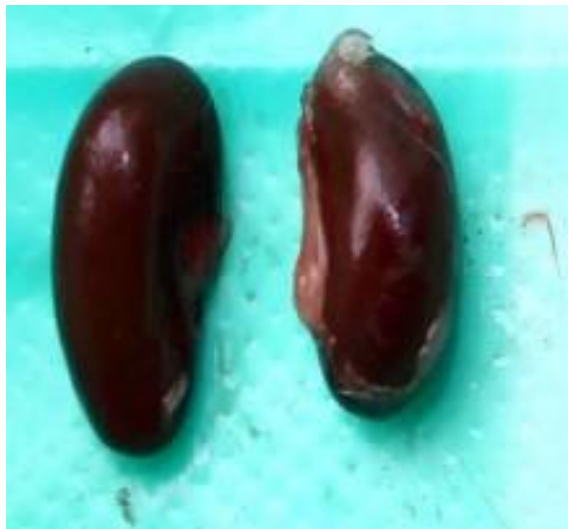

2.(A)

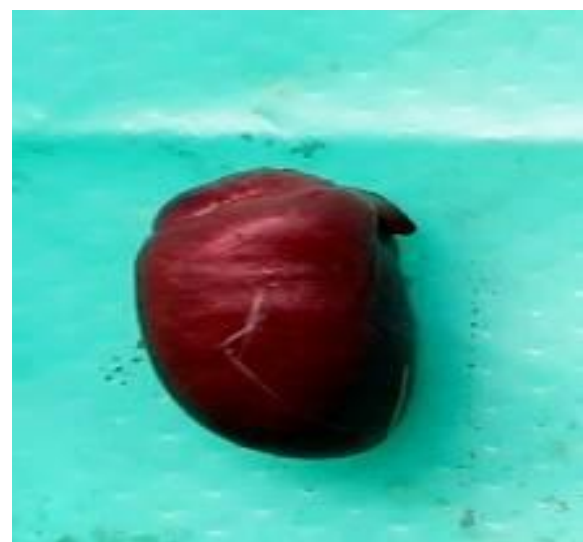

3(A) 3(B)

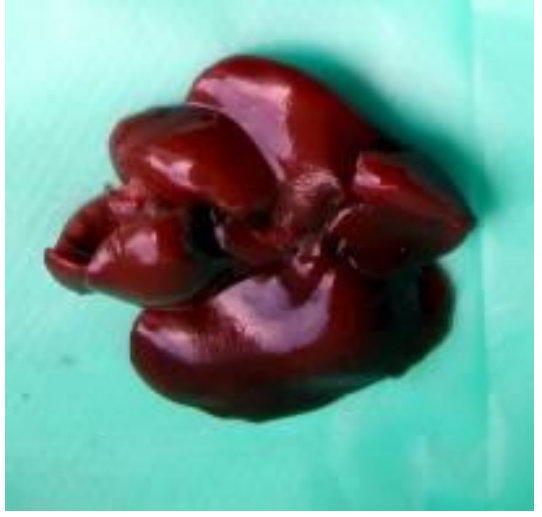

1.(B)

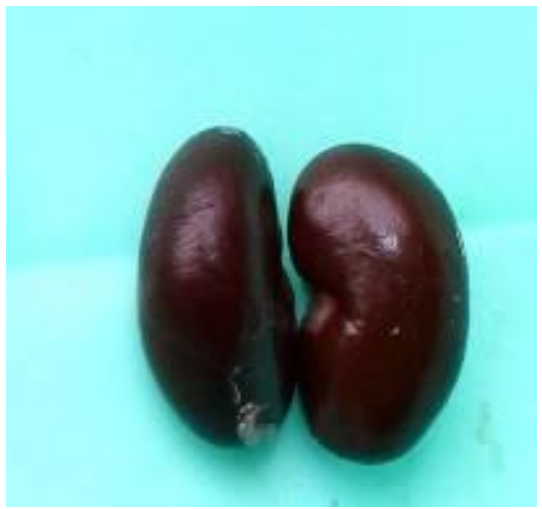

2.(B)

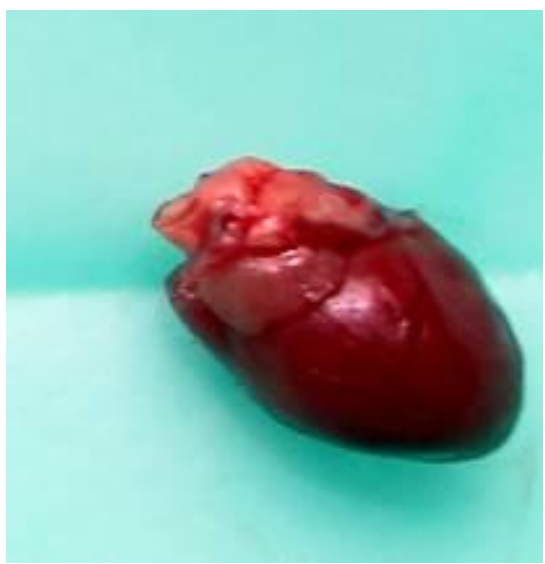


Fig.5 Section of Liver with congestion, focal MNC infiltration and degenerative changes (H \& E Stain, X400)

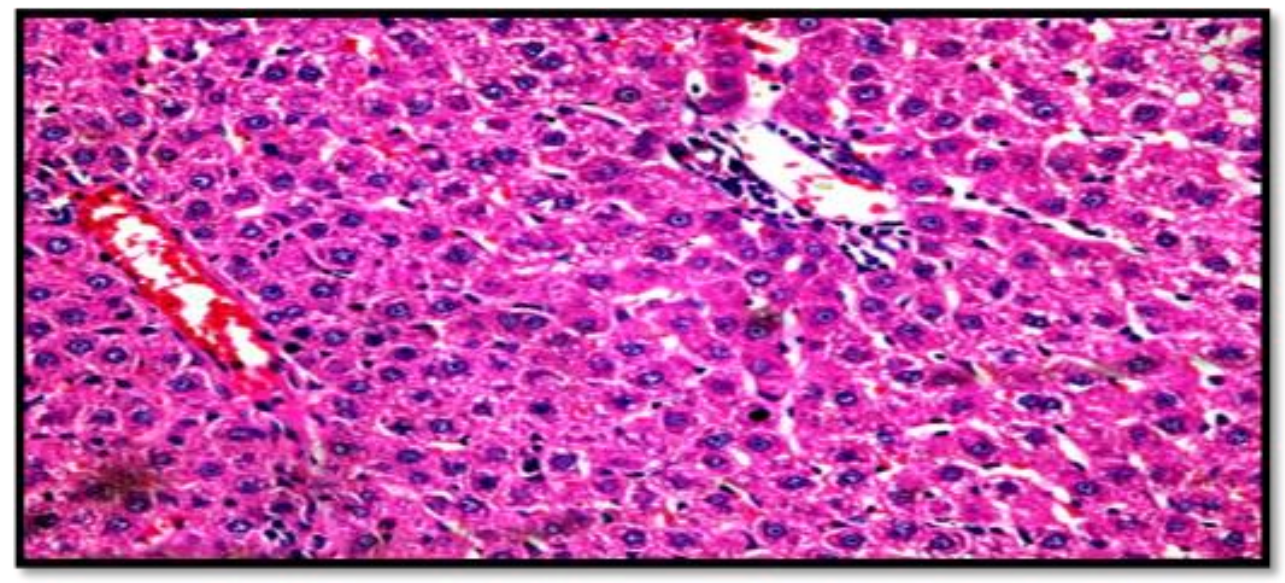

Fig.6 Note Multifocal fatty change and MNC infiltration in parenchyma of liver (H\&E Stain, X400)

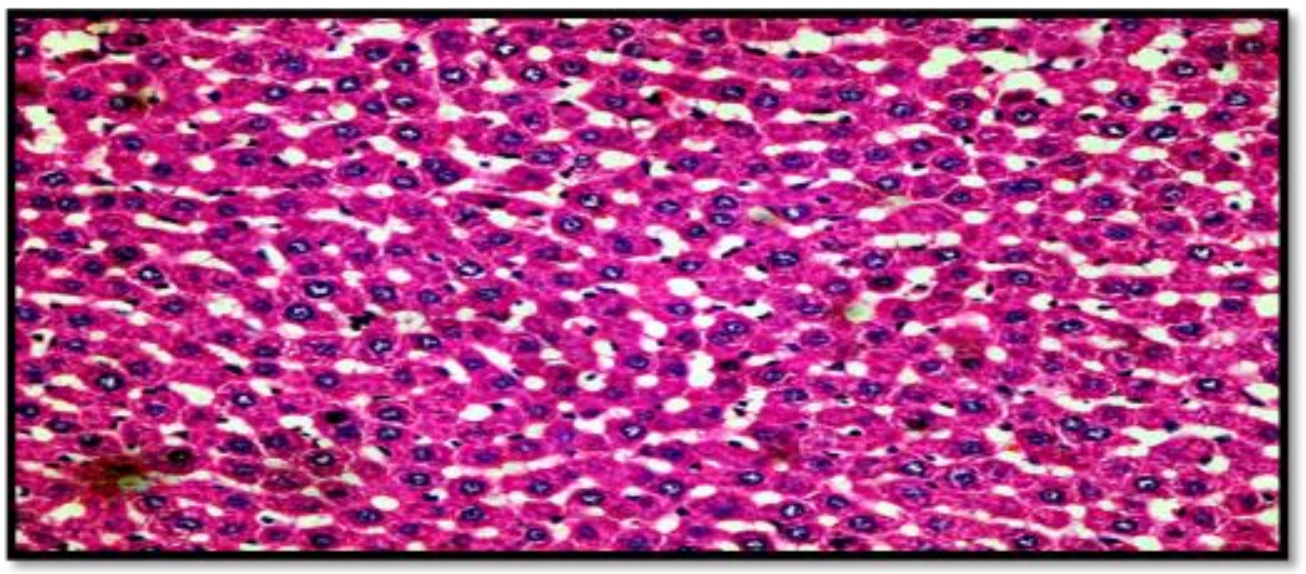

Fig.7 Liver with moderate cytoplasmic rarefication and occasional fatty change (H \& E Stain, X400)

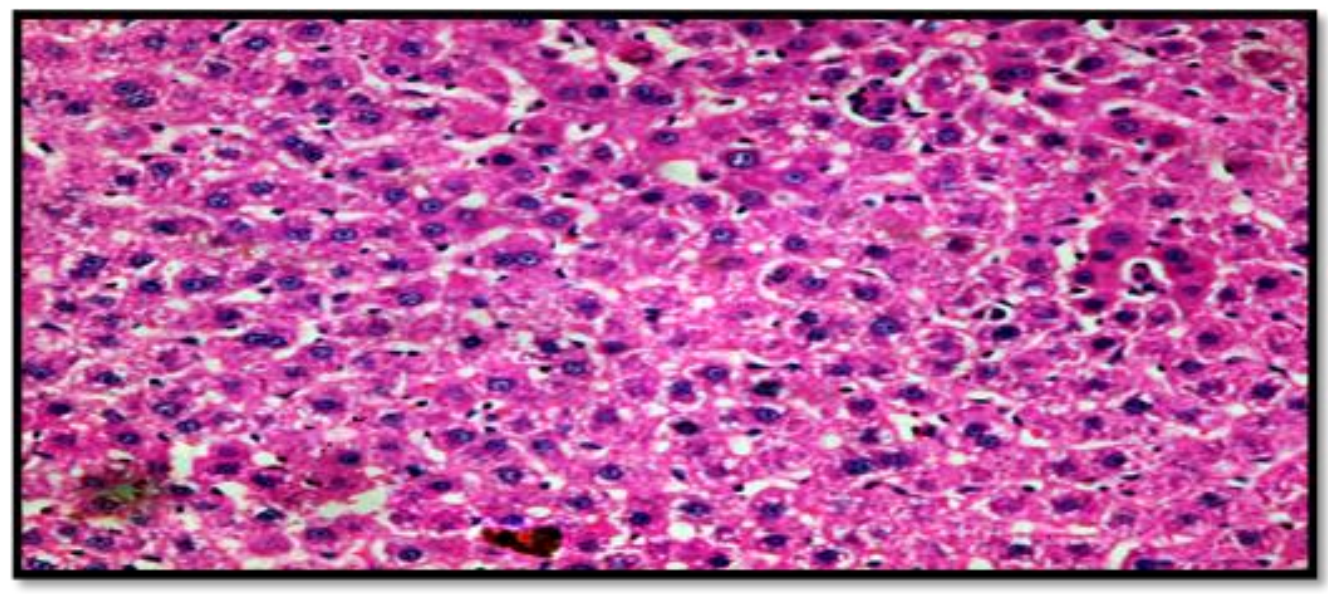


Fig. 8 Note congestion and MNC infiltration in Kidney (H \&E Stain, X400)

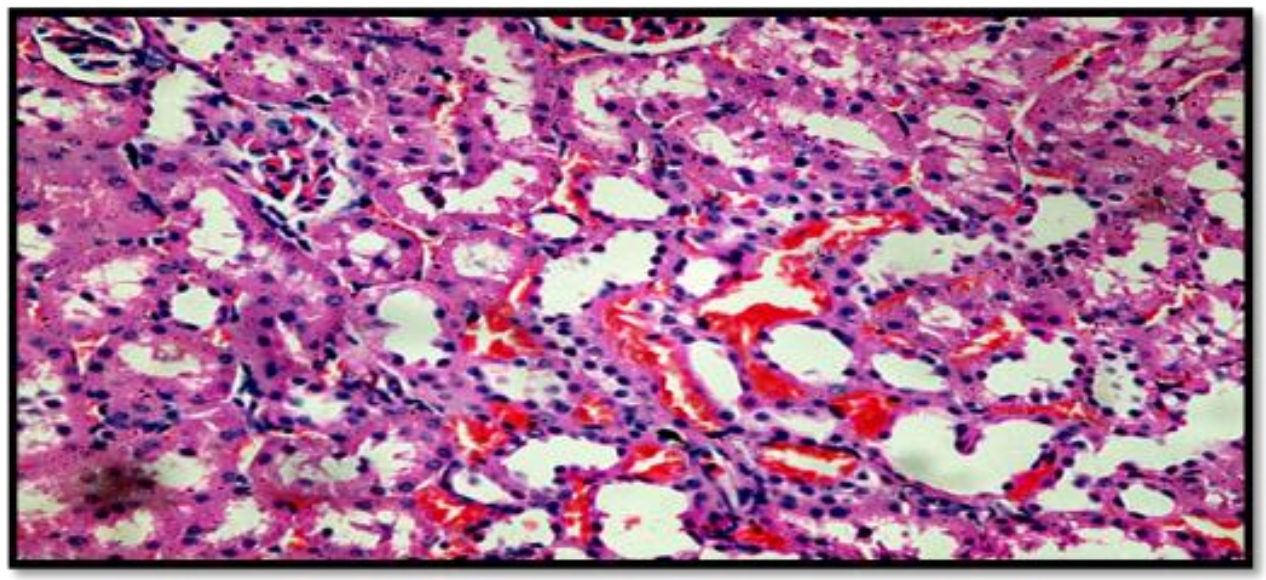

Fig. 9 Note multifocal cystic, vacuolar degenerative changes and MNC infiltration in Kidney $(\mathrm{H}$ \& E Stain, X100)

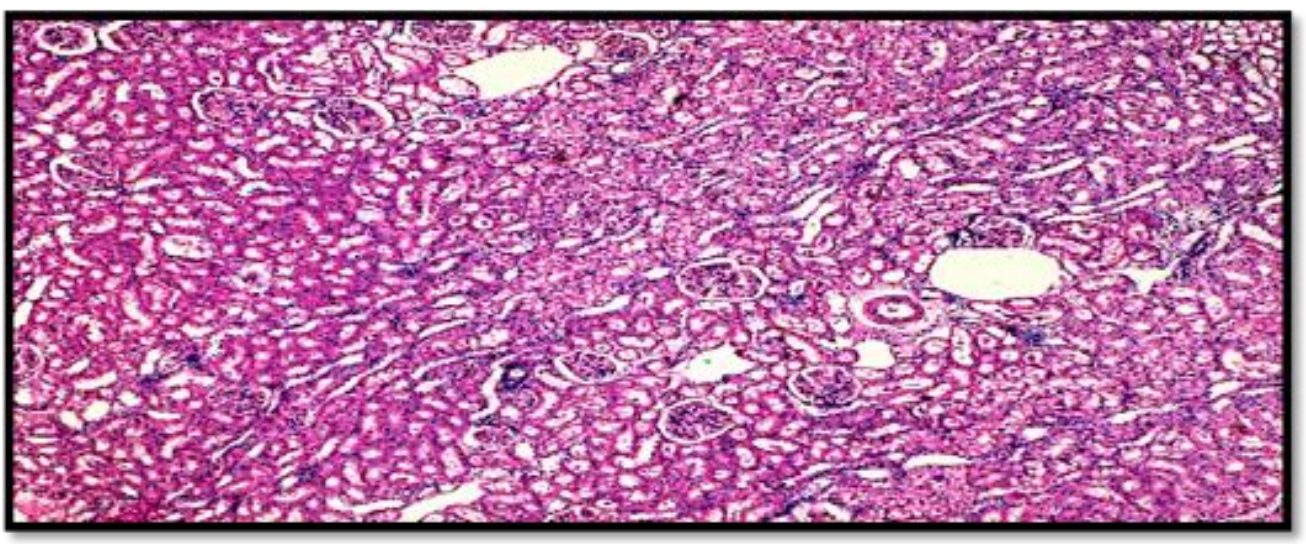

Fig.10 Section of a Kidney with vacuolar degenerative changes, necrobiotic changes and MNC infiltration (H \& E Stain, X400)

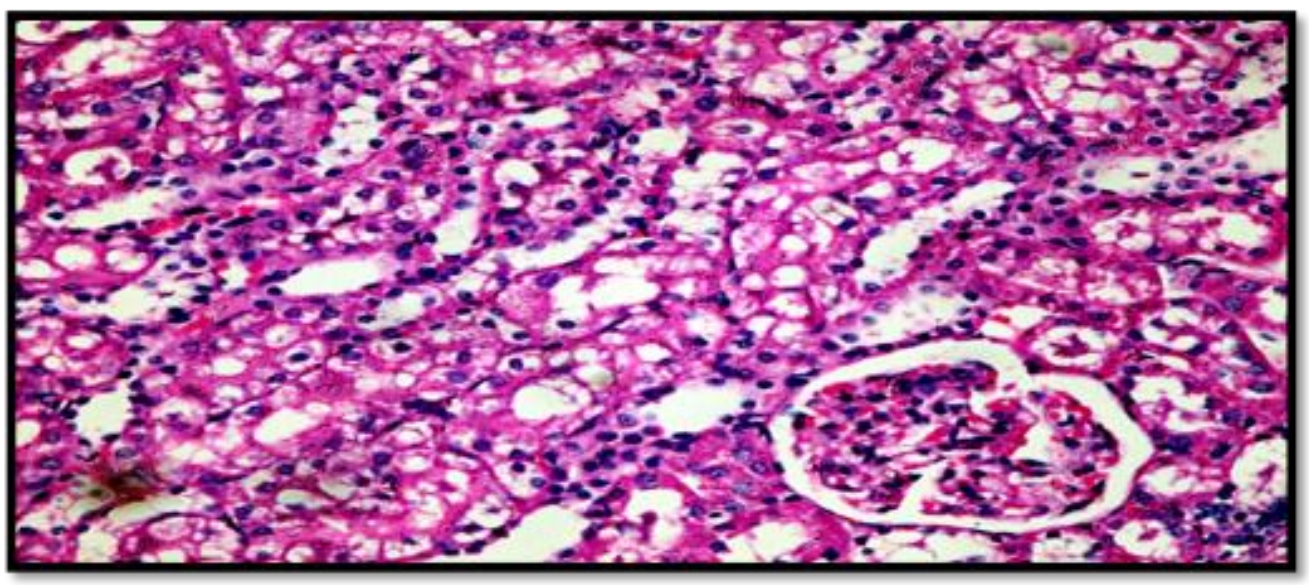


Fig.11 Focal hyaline cast in lumen of PCT and necobiotic changes in affected tubules $(\mathrm{H} \& \mathrm{E}$ Stain, X400)

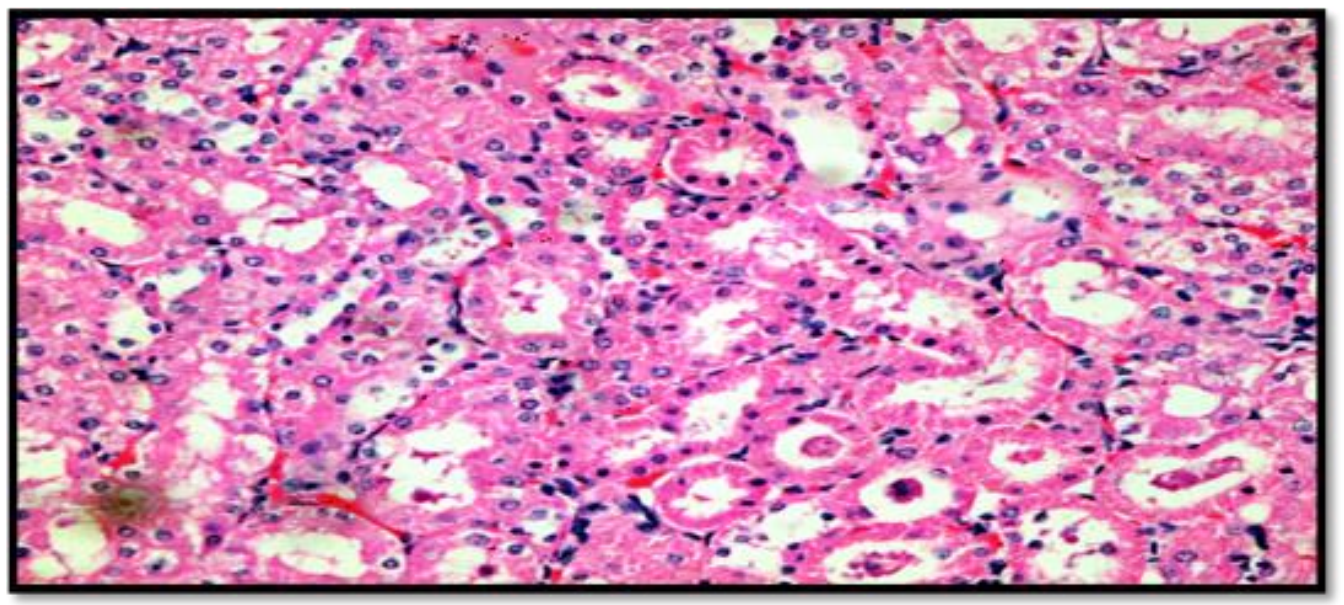

Fig.12 A section of skin with normal histoarchitecture (H \& E Stain, X100)

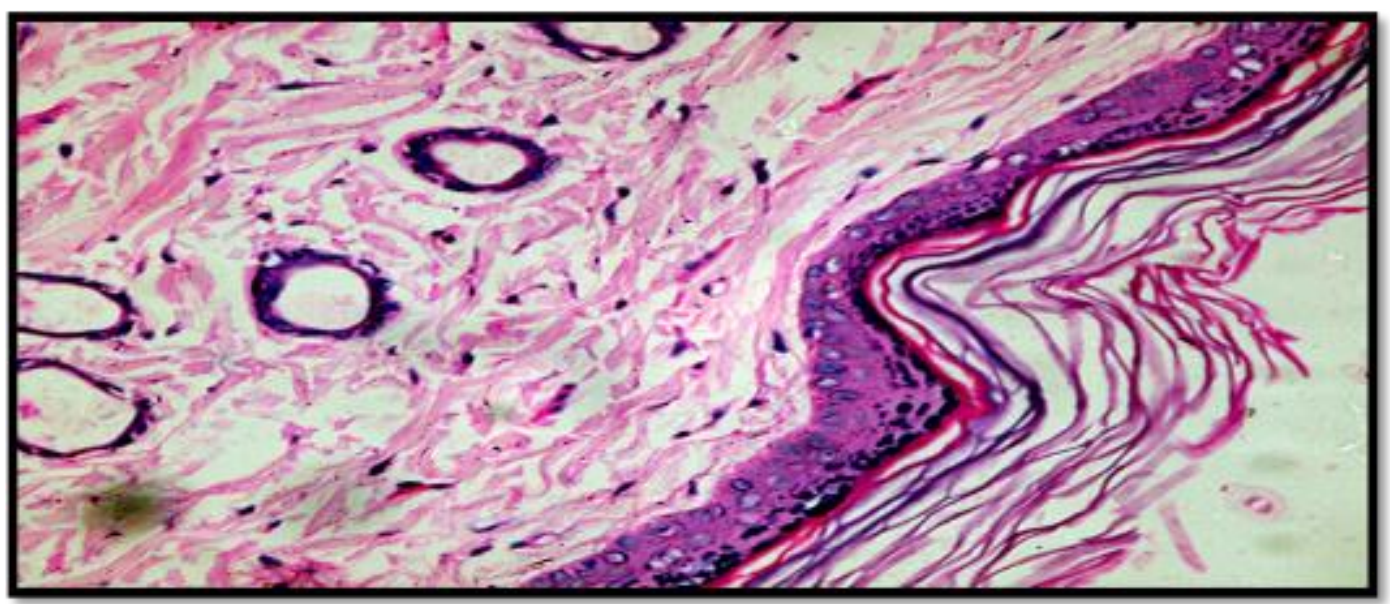

Fig.13 A section of skin with normal histoarchitecture (H \& E Stain, X400)

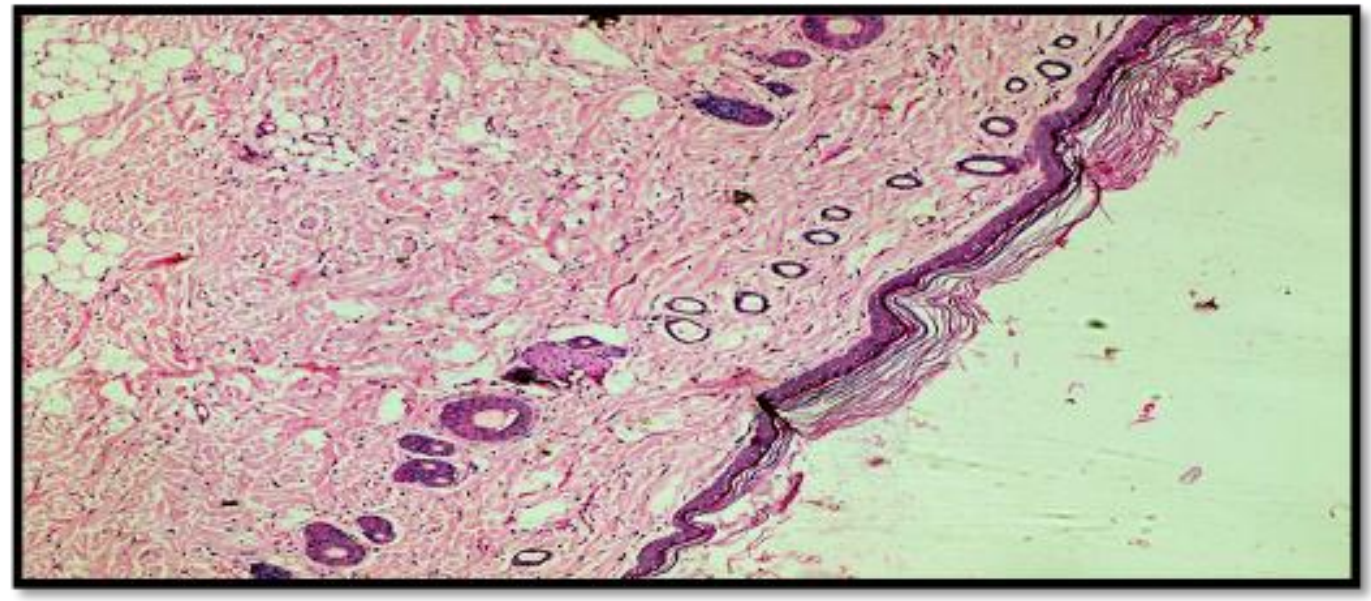


Table.1 Experimental design

\begin{tabular}{|c|c|c|c|c|}
\hline Group & Name of Group & Treatment & Dose & Route \\
\hline I & Healthy control & Deionised water & $1 \mathrm{ml}$ & Dermal \\
\hline \multirow[t]{2}{*}{ II } & \multirow{2}{*}{$\begin{array}{c}\text { Morinda citrifolia fruit } \\
\text { extract Coated GNP } \\
\text { Dose }- \text { I }\end{array}$} & Gold nanoparticles & @ $1 \mathrm{mg} / \mathrm{kg} \mathrm{Bwt}$. & \multirow[t]{2}{*}{ Dermal } \\
\hline & & $\begin{array}{c}\text { Morinda citrifolia fruit } \\
\text { extract }\end{array}$ & 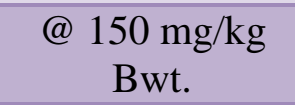 & \\
\hline \multirow[t]{2}{*}{ III } & \multirow{2}{*}{$\begin{array}{c}\text { Morinda citrifolia fruit } \\
\text { extract Coated GNP } \\
\text { Dose-II }\end{array}$} & Gold nanoparticles & @ $2 \mathrm{mg} / \mathrm{kg} \mathrm{Bwt}$. & \multirow[t]{2}{*}{ Dermal } \\
\hline & & $\begin{array}{c}\text { Morinda citrifolia fruit } \\
\text { extract }\end{array}$ & $\begin{array}{c}\text { @ } 300 \mathrm{mg} / \mathrm{kg} \\
\text { Bwt. }\end{array}$ & \\
\hline \multirow[t]{2}{*}{ IV } & \multirow{2}{*}{$\begin{array}{l}\text { Morinda citrifolia fruit } \\
\text { extract Coated GNP } \\
\text { Dose - III }\end{array}$} & Gold nanoparticles & @ 4 mg/kg Bwt. & \multirow[t]{2}{*}{ Dermal } \\
\hline & & $\begin{array}{c}\text { Morinda citrifolia fruit } \\
\text { extract }\end{array}$ & $\begin{array}{c}\text { @ } 600 \mathrm{mg} / \mathrm{kg} \\
\text { Bwt. }\end{array}$ & \\
\hline \multirow[t]{2}{*}{ V } & \multirow[t]{2}{*}{ Satellite Group } & Gold nanoparticles & @ $8 \mathrm{mg} / \mathrm{kg} \mathrm{Bwt.}$ & \multirow[t]{2}{*}{ Dermal } \\
\hline & & $\begin{array}{c}\text { Morinda citrifolia fruit } \\
\text { extract }\end{array}$ & $\begin{array}{c}\text { @ } 1200 \mathrm{mg} / \mathrm{kg} \\
\text { Bwt. }\end{array}$ & \\
\hline
\end{tabular}

Table.2 Relative Organ weights in grams (Mean $\pm \mathrm{SE}$ ) in experimental rats at the end of the study period $\left(28^{\text {th }}\right.$ day $)$

\begin{tabular}{|c|c|c|c|c|}
\hline \multirow{2}{*}{ Gr. } & \multirow[b]{2}{*}{ Treatment } & \multicolumn{3}{|c|}{ Days } \\
\hline & & $\begin{array}{c}\text { Liver } \\
\text { (Mean } \pm \text { S.E. })\end{array}$ & $\begin{array}{c}\text { Heart } \\
\text { (Mean } \pm \text { S.E. })\end{array}$ & $\begin{array}{c}\text { Kidney } \\
\text { (Mean } \pm \text { S.E.) }\end{array}$ \\
\hline I & Healthy control & $\begin{array}{l}8.45 \pm^{\mathrm{a}} \\
0.71\end{array}$ & $\begin{array}{c}0.94 \pm^{b} \\
0.04\end{array}$ & $\begin{array}{c}2.02 \pm^{\mathrm{ab}} \\
0.12\end{array}$ \\
\hline II & $\begin{array}{l}\text { Morinda citrifolia fruit extract } \\
\text { coated GNP dose-I }\end{array}$ & $\begin{array}{c}8.37 \pm^{\mathrm{a}} \\
0.41\end{array}$ & $0.94 \pm^{\mathrm{b}}$ & $\begin{array}{c}2.24 \pm^{\mathrm{a}} \\
0.11\end{array}$ \\
\hline III & $\begin{array}{l}\text { Morinda citrifolia fruit extract } \\
\text { coated GNP dose-II }\end{array}$ & $\begin{array}{c}8.14 \pm^{\mathrm{a}} \\
0.40\end{array}$ & 0.11 & $1.98 \pm^{\mathrm{ab}}$ \\
\hline IV & $\begin{array}{l}\text { Morinda citrifolia fruit extract } \\
\text { coated GNP dose-III }\end{array}$ & $\begin{array}{l}7.82 \pm^{\mathrm{a}} \\
0.41\end{array}$ & $\begin{array}{c}1.21 \pm^{\mathrm{a}} \\
0.08\end{array}$ & $\begin{array}{c}1.79 \pm^{b} \\
0.09\end{array}$ \\
\hline $\mathbf{V}$ & Satellite group & $\begin{array}{c}6.65 \pm^{\mathrm{a}} \\
0.36\end{array}$ & $0.91 \pm^{b}$ & $1.78 \pm^{b}$ \\
\hline Stat & & NS & HS & NS \\
\hline CD & & \multicolumn{3}{|c|}{ At $5 \% 0.22$ At $1 \% 0.31$} \\
\hline
\end{tabular}


Application of nanotechnology to healthcare, holds great promise for revolutionizing medical treatments and therapies in areas, such as imaging, drug delivery, faster diagnosis and tissue regeneration, as well as the development of new medical products. Recently their safety evaluation is a major concern for certifying them whether toxic or nontoxic to be applied in therapeutics and diagnostics rampantly. Different sizes, surface modifications, surface charges, have different interaction capacity to living body system, which significantly differ from in-vitro toxicity trials as gold nanoparticles interaction in live tissue and organ in body varies from cell line studies. Morinda citrifolia is a novel plant with different medicinal property like anti-diabetic, anticancer, antihyperlipidemic and many more establish in several studies. In a previous study, antidiabetic effect of GNPs and Morinda citrifolia fruit extract (McFE) coated GNPs were established so this experiment was designed to evaluate the toxicity of McFE Coated GNPs in variable doses as there were very less in- vivo toxicity studies conducted for gold nanoparticles.

The present experiment was undertaken to pathomorphological assessment of sub-acute dermal toxicity of Morinda citrifolia Linn. fruit extract coated gold nano particles in Wistar rats under experimental conditions. 50 rats of either sex were divided into five groups comprising of ten rats in each group. In group I rats were kept as healthy control. In group II, III and IV were treated with different doses of Morinda citrifolia aqueous fruit extract (McFE) coated gold nanoparticles (GNPs). The last group (Group-V) is satellite group, the rats were kept additional 14 days post treatment. The dose ( $\mathrm{mg} / \mathrm{kg}$ body weight) combinations were $1 \mathrm{mg} / \mathrm{kg}$ GNPs with $150 \mathrm{mg} / \mathrm{kg}$ McFE (low dose), $2 \mathrm{mg} / \mathrm{kg}$ GNPs with $300 \mathrm{mg} / \mathrm{kg}$ McFE (medium dose), $4 \mathrm{mg} / \mathrm{kg}$ GNPs with McFE $600 \mathrm{mg} / \mathrm{kg}$ (high dose) respectively. In last group rats were treated as satellite group in which rats were dosed with $8 \mathrm{mg} / \mathrm{kg}$ GNPs with $1200 \mathrm{mg} / \mathrm{kg} \mathrm{McFE}$ (highest dose) and observed for additional 14 days post treatment duration (28 days) to access adverse reaction after withdrawal of treatment. Aqueous extract of Morinda citrifolia fruit was made using cold extraction method, and the extractability was found to be $4.46 \%$. Gold nanoparticles were synthesized by biological reduction (green synthesis) of chloroauric acid $\left(\mathrm{HAuCl}_{4} \cdot 3 \mathrm{H}_{2} \mathrm{O}\right)$ with Azadirachta indica (neem) leaf extract, after coating the characterization of GNPs by colour changes deep[ yellow to ruby red was confirmed. These nanoparticles were coated with Morinda citrifolia fruit extract (McFE) which was used for the treatment.The toxicity of McFE Coated GNPs combination treatments on gross pathology, absolute organ weights and histopathological changes in liver, kidney and skin were investigated in experimental rats.The experiment rats from healthy control group did not show any apparent behavioral changes.

Gross pathological observations of liver, kidney and skin indicated mild to moderate haemorrhages, congestion and mild architectural alteration especially in liver and kidney with highest dose of coated GNPs. Organ weights differ highly significantly except liver indicating liver was the primary target of GNPs treatment after dermal administration.

In comparison with the control group, the following histological alterations were detected in the liver tissue of high dose Morinda citrifolia fruit extract coated GNPstreated Wistar rats. The histopathological alterations of liver in treated groups showed dilatation of central vein and sinusoidal space, diffused necrobiotic and focal fatty changes with mononuclear cells infiltration. Higher doses produced more damage than their respective low doses. The vacuolated swelling 
of the cytoplasm of the hepatocytes of theMorinda citrifolia fruit extract coated GNPs-treated rats might indicate acute and sub-acute liver injury induced by these nanoparticles. The Morinda citrifolia fruit extract coated GNPs-treated rat which received high dose demonstrated vacuolar degeneration, vacuolization of the renal cells was seen and increased in severity in the renal tubules. Hyaline casts were detected in the renal epithelium of rats which received high dose of McFE coated GNPs. (fig no 11). The liver are considered as a dominant organs for biodistribution and metabolism of GNPs [27, 34-36]. If GNPs are larger than renal filtration cutoff, they are not excreted in urine; instead they are eliminated from the blood by the reticuloendothelial system and thus tend to accumulate in the liver [34, 37].Nanoparticles fortherapeutic use need to have a long retention time in orderto encounter and interact with the desired target. However,a long retention time can result in toxic effects. Thus,route and rate of nanomaterial clearance is an important issue.The increasing usage of nanoparticles especially $\mathrm{Au}$ nanoparticles for biomedical purposes necessitates the safety evaluation of these nanoparticles. Recent findings have shown that nanoparticles, because of their small sizes, behave differently from the parent material and have potential to predispose to oxidative cellular damage (Hudecova et al.,., 2012; Adeyemi and Faniyan, 2014). The increase in GNPs levels might be an indication of injured hepatocytes due to GNPs toxicity that became unable to deal with the accumulated residues resulting from metabolic and structural disturbances caused by these NPs (Abdelhalim \& Jarrar, 2011). The main lesions in the kidney characterized by mononuclear cells infiltration around congested blood vessels with vacuolar degeneration of epithelial cells of renal tubules as shown in (Figures. 11). This implies that surface functionalization or coatings of GNPs has a very huge impact on the toxicity of nanomaterials. However, Morinda citrifolia fruit extract coated GNPs appeared low impact on tissue liver and kidney. The changes in kidney was multifocal cysts with vacuolar degeneration of epithelial cells of renal tubules as shown in (Figure.9) necrobiotic changes with mononuclear cell infiltration and also characterized by multifocal cysts in kidney as shown in (Figure.9).

From present investigations it can be concluded that, Azadirachta indica leaf extract can be used to produce gold nanoparticles by biological reduction method and gold nanoparticles can be coated with Morinda citrifolia fruit extract

On gross and histopathological examination, very minimal alterations are observed in liver and kidney in a dose dependent manner related to toxicity and skin organs studied are found to be normal. A chronic toxicity trial is appealed to understand the extent of toxicity.

\section{Acknowledgement}

The author thanks to the Major guide for providing the technical support and the Department of Veterinary Pharmacology and Toxicology and Department of Veterinary Pathology, COVAS, Parbhani for providing the necessary facility to conduct this study.

\section{References}

Abdelhalim MAK, Jarrar BM. 2011. Gold nanoparticles induced cloudy swelling to hydropic degeneration, cytoplasmic hyaline vacuolation, polymorphism, binucleation, karyopyknosis, karyolysis, karyorrhexis and necrosis in the liver. Lipids in Health and Disease, 10 (166): 1-6.

Abdelhalim MAK, Moussa SAA. 2013. The gold nanoparticle size and exposure duration effect on the liver and kidney 
function of rats: In vivo. Saudi Journal of Biological Sciences, 20: 177-181.

Adeyemi, OS, Adewumi I, Faniyan TO. 2014. Silver nanoparticles influenced rat serum metabolites and tissue morphology. J. Basic Clin. Physiol. Pharmacol. 10.1515/jbcpp-2013-0092

Balasubramanian SK, Jittiwat J, Manikandan J, Ong CN,Yu LE, Ong WY. 2010. "Biodistribution of gold nanoparticlesand gene expression changes in the liver and spleen afterintravenous administration in rats,"Biomaterials, vol. 31, no. 8,pp. 2034-2042.

Chandran, S.P., SP, Chaudhary M, Pasricha R, Ahmad A, Sastry M. 2006. Gold Nanotriangles and Silver Nanoparticles using Aloe vera plant extract, Biotechnology Progress, 577 - 583.

Chen YS, Hung YC, Liau I, Huang GS. 2009. "Assessmentof the in vivo toxicity of gold nanoparticles," Nanoscale ResearchLetters, vol. 4, no. 8, pp. 858864.

Culling CFA. 1974. Handbook of Histopathological and Histochemical Techniques, Edn.III Buttercorth and Co. Ltd. London. PP: 209-221.

Ghosh P, Han G, De M, Kim CK, Rotello VM. 2008. Gold nanoparticles in delivery applications.Adv Drug Deliv Rev 2008;60:1307-15.

Guo R, Song Y, Wang G, Murray RW. 2005. Does core size matter in the kinetics of ligand exchanges of monolayerprotected Au clusters? J Am ChemSoc, 127:2752-2757.

Gupta RK, Banerjee A, Pathak S, Sharma C, Singh N. 2007. Induction of mitochondrial-mediated apoptosis by Morinda citrifolia (noni) in human cervical cancer cells. Asian Pac J Cancer Prev.2013;14(1):8491.

Hudecova, A, Kusznierewicz B, Runden-Pran E, Magdolenova Z, Hasplova K. 2012.
Silver nanoparticles induce premutagenic DNA oxidation that can be prevented by phytochemicals from Gentiana asclepiadea. Mutagenesis. 10.1093/ mutage/ges046

Jong WHD, Hagens WI,Krystek P, Burger MC, Sips AJ AM, Geertsma RE. 2008., "Particle size dependent organ distributionof gold nanoparticles after intravenous administration,"Biomaterials, vol. 29, no.12, pp. 1912-1919.

Kumar M, Verma D. 2011. Antidiabetic and antihyperlipidemic effect of Morinda Citrofolia andCoccinia indica in alloxan induced diabetic rats. Pharmacologyonline2: 307-311.

Lames TH AL-H, Azhar JAL-M, Ali AT. 2016. Toxic effects of fabricated gold nanoparticles in albino mice. International Research Journal of Agricultural and Food Sciences.; 1(1):116.

McClatchey W.2002. From Polynesian healers to health food stores: changing perspectives of Morinda citrifolia (Rubiaceae). Integral Cancer Therapy, 1: $110-120$.

Nelson SC. 2006. Morinda citrifolia (noni), ver. 4. In:Elevitch, C.R., (Ed.), Species Profiles for Pacific Island Agroforestry. Permanent Agriculture Resources (PAR), Holualoa, Hawaii.

OECD Guideline for Testing of Chemicals TG-410. Repeated dose 21/28- day dermal toxicity study in rodents.

Panse UG,Sukhatme PV. 1967. Statistical methods for Agricultural workers, ICAR, Publication New Delhi.

Paris, France: Organisation for Economic Cooperation and Development; 12 May 1981

Pokharkar, Dhar S,Bhumkar D, Mali V, Bodhankar S, Prasad BLV. 2009. Acute and subacute toxicity studies of chitosan reduced gold nanoparticles: A Novel 
carrier for therapeutic agents, Journal of Biomedical Nanotechnology Vol. 5(3):1-7.

Raghunathan K. 1976. Pharmacopeial Standards of Ayurvedic Formulations. 15, New Delhi India, Centra Council for Research in Indian Medicine Homeopathy (CCRIMH) Publ; 1976.

Rivera A, Giono S, Gonzalez M, Rodríguez N, Cedillo L. 2011. Antibacterial effect of Morinda citrifolia fruit juice against mycoplasmas. Annals of Biological Research, 2 :491-497.

Semmler-Behnke M, Kreyling WG, Lipka J. 2008. "Biodistribution of 1.4- and 18nm gold particles in rats," Small, vol. 4, no. 12, pp. 2108-2111, 2008.

Sulaiman FA, Akanji MA, Oloyede HOB, Sulaiman AA, Olatunde A, Joel EB, Adewale TL,Adeboye HA, Idris SO, Quadri AL, Oyegoke RA, Adeyemi OS. 2015. Oral Exposure to Silver/Gold Nanoparticles: Status of Rat Lipid

\section{How to cite this article:}

Pawar, A. R., S. R. Rajurkar, N. D. Jadhav, G. R. Gangane and Bhalchim, S. 2019. Pathomorphological Assessment of Sub-Acute Dermal Toxicity of Morinda citrifolia Linn. Fruit Extract Coated Gold Nano Particles in Wistar Rats. Int.J.Curr.Microbiol.App.Sci. 8(09): 1160-1175. doi: https://doi.org/10.20546/ijcmas.2019.809.133
Profile, Serum Metabolites and Tissue Morphology. Journal of Medical Sciences. 15 (2): 71-79.

Von Maltzahn G, Park JH, Agrawal A. 2009. "Computationallyguided photothermal tumor therapy using longcirculatinggold nanorod antennas," Cancer Research, vol. 69, no. 9, pp.3892-3900, 2009.

Wang MY, Lutfiyya MN, WeidenbacherHoper V. 2009. Antioxidant activity of Noni juice in heavy smokers. Chem Cent J, 3, 13.

Zahi AK., Hamzah H, Hutheyfa S, Mohd R. Shaari, Sithambaram S, Othman HH. 2015. Acute And Sub-Acute Dermal Toxicity Studies of Morinda citrifolia $\mathrm{L}$. Fruit Extract in Sprague Dawley Rats. Asian J Pharm Clin Res, 8(2): 400-408.

Zhao H, and Ning Y. 2001. China's Ancient Gold Drugs, Gold Bull;34:24-9. 